\title{
A Basic Review and Some Guidelines for Planning New Facilities
}

\author{
by Norman J. Snelling
}

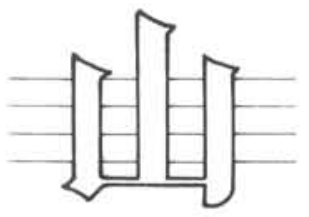

In this short review the Chairman of the IUGS Subcommission on Geochronology reminds readers of some of the basic principles and modern techniques involved in the isotopic dating of rocks and minerals. He makes several practical suggestions to those contemplating the setting up of new laboratories, especially in developing countries, and the services of the Subcommission are offered for those seeking further information.

- Editor

\section{The Historical Background}

Geochronology in the sense of dating rocks and minerals using the phenomenon of radioactive decay came into being soon after the beginning of this century. At that time scientists investigating the newly discovered phenomenon of radioactivity realized that by measuring the amount of radiogenic 'daughter' products formed in a given period of time they could estimate the rate of radioactive decay of the parent element. The reverse application of this approach followed almost immediately, that is, knowing the rate of decay and measuring the amounts of parent element and daughter product, the age of the system could be calculated.

The first results used naturally occurring uranium-bearing minerals and immediately indicated that geological time was to be measured in hundreds of millions of years. This had long been argued by geologists on the basis of numerous verifiable observations, but was questioned by physicists who could not see from where the energy came to keep the solar system going for more than a hundred million years. The study of radioactivity was thus the forerunner of our understanding of the energy source of the solar system, and indeed of the cosmos, as well as the answer to the geologists' quest for a natural time keeper that could be calibrated in conventional time units - normally millions of years (Ma).

For the first half of this century geochronology made slow but steady progress. By the 1920 s it was clear that Phanerozoic time extended over about $500 \mathrm{Ma}$, while Precambrian rocks were yielding ages in excess of $2000 \mathrm{Ma}$. The next major breakthrough came in the 1930s with a technological development. This was the design and construction by the American physicist and engineer Alfred Nier of the forerunner of the present day mass spectrometer, an instrument of fundamental importance to geochronology but unfortunately a very expensive one (Fig. 1).

\section{The Basics}

The essential function of the mass spectrometer is to separate and measure atomic and molecular species using the principle that charged particles follow curved trajectories when accelerated in a magnetic field. The radius of curvature of the trajectory of a particle depends in part on its mass. Thus atomic and molecular particles of different masses can be separated and measured in a way analogous to the splitting up of light into the 'colours of the rainbow' by passing it through a glass prism.

To illustrate the application of the mass spectrometer to geochronology let us consider the basis of the potassiumargon method. A very small proportion (approximately 1.2 $\mathrm{ppm}$ ) of natural potassium is radioactive. This isotope, with a mass number 40 , decays in part to the inert gas argon with the same mass number. Since ${ }^{40} \mathrm{~K}$ is a fixed proportion of natural potassium, its determination in any sample involves only the measurement of the total $\mathrm{K}$ content of a rock or mineral and multiplying the result by the appropriate factor.

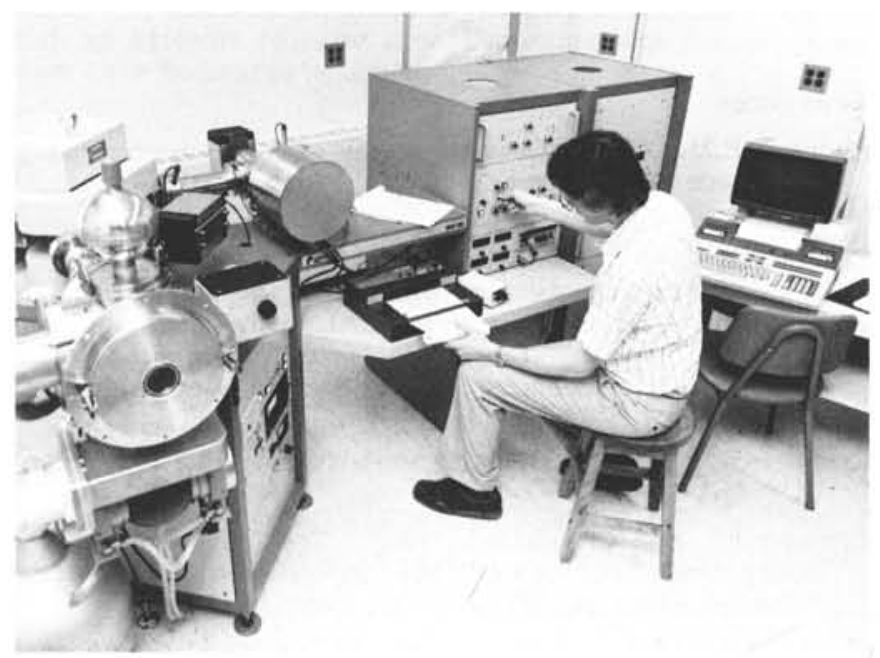

Figure 1: Multi-collector Finnigan-MAT 261 mass spectrometer at Department of Geology, Carleton University, Ottawa.

To determine the argon content of a rock or mineral the sample is fused in a vacuum system, and the Ar separated from other gases evolved during the fusion simply by making use of its inert chemical nature. The amount of Ar can be measured directly, or more commonly nowadays determined 
by the method of isotope dilution (see below). However, there is a significant amount (1\%) of potentially contaminating ${ }^{40} \mathrm{Ar}$ in the atmosphere, and since no vacuum system is perfect there is usually a small amount of atmospheric ${ }^{40} \mathrm{Ar}$, the apparatus blank, which must be distinguished from the ${ }^{40} \mathrm{Ar}$ formed in the rock or mineral being dated. For tunately, atmospheric argon contains very small amounts of ${ }^{36} \mathrm{Ar}$ with a fixed ratio ${ }^{48} \mathrm{Ar}$ to ${ }^{36} \mathrm{Ar}$ of 295.5 , and even lesser amounts of ${ }^{38} \mathrm{Ar}$. These isotopes can be detected by the mass spectrometer and the equivalent amount of atmospheric ${ }^{40} \mathrm{Ar}$ calculated and subtracted from the total ${ }^{40} \mathrm{Ar}$ to leave the radiogenic component.

Similar corrections can be made when determining radiogenic strontium and lead. In the former case ${ }^{86} \mathrm{Sr}$ and in the latter case ${ }^{204} \mathrm{~Pb}$ serve as the non-radiogenic monitors. This is not, however, the end of the problem, for very little of the nonradiogenic strontium or lead originates as a contaminant like ${ }^{40} \mathrm{Ar}$. Most of the strontium or lead encountered in geochronological analysis was incorporated in the rocks or minerals when they first crystallized. Unlike the isotopic composition of the contaminating atmospheric argon which is constant, the isotopic composition of the incorporated nonradiogenic strontium or lead is variable, the variation reflecting both the age of the sample and its genesis.

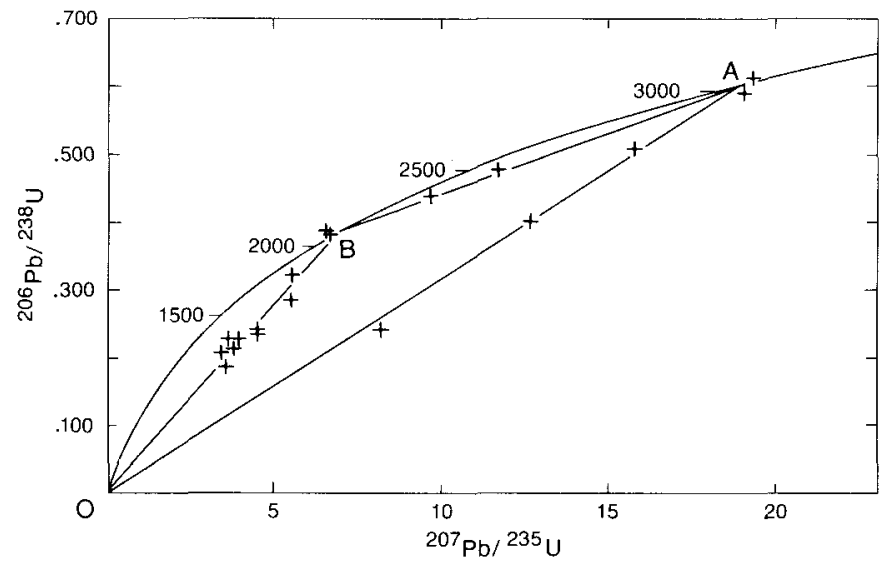

Figure 2: Concordia plots for uraniferous minerals of the Witwatersrand conglomerates (after Rundle and Snelling, 1977).

The analyst is therefore faced with two variables the age of the sample and the isotopic composition of the incorporated or common non-radiogenic strontium or lead. With only one sample the age can be calculated only if assumptions are made concerning the second variable. Although ages were calculated in this way until the late 1950 s, the resultant ambiguity, particularly for $\mathrm{Rb}: \mathrm{Sr}$ ages which are very sensitive to the common strontium correction, resulted in the method being abandoned. Nowadays it is customary, particularly in Rb:Sr studies, to analyze two or more samples from the occurrence under investigation, assuming that the samples are of the same age and had non-radiogenic $\mathrm{Sr}($ or $\mathrm{Pb}$ ) of the same isotopic composition. Thus with two or more samples analyzed the two unknown variables - age and the isotopic composition of the common strontium or lead - can be determined independently.

This method, as applied to $\mathrm{Rb}: \mathrm{Sr}$ dating, was introduced at a meeting of the New York Academy of Sciences held in 1960, a meeting that can be looked upon as the coming-of-age of geochronology. However, the whole approach had been modelled by Arthur Holmes in 1932 in a little-known paper which can best be described as a remarkable example of the foresight of genius.
The final breakthrough in geochronology came during the years of the Second World War with the production of 'isotopic tracers' - elements with abnormal isotopic compositions. For example, normal strontium contains less than $0.5 \%$ strontium-84, but an isotopic tracer is available consisting almost entirely of ${ }^{84} \mathrm{Sr}$. These tracers allow a very accurate calibration of the mass spectrometer so that it can determine by the technique of isotope dilution mere traces of all the elements of interest to the geochronologist and, in addition, isotope ratios indicative of the proportions of radiogenic and non-radiogenic isotopes. As a result the mass spectrometer has become an essential analytical tool, and age determinations can be made on rocks and minerals containing only trace amounts (ppm levels) of the parent and daughter isotopes.

Since 1960 geochronologists have been able to date a wide variety of rocks and minerals with increasing accuracy and precision. The three main lines of attack have been the $\mathrm{K}: \mathrm{Ar}$, the $\mathrm{Rb}: \mathrm{Sr}$ and the $\mathrm{U}: \mathrm{Pb}$ methods, and these have been joined recently by the method depending on the alpha decay of samarium-147 to neodymium-143.

\section{The Uranium-Lead Method}

The U:Pb method is perhaps the most powerful technique of age determination. Originally it was applied to uraniferous minerals from pegmatites and veins and indeed such samples are still dated, the results often providing direct evidence of the age of mineralization. However it has been in the application to the accessory minerals, particularly zircon, in igneous and metamorphic rocks that the $\mathrm{U}: \mathrm{Pb}$ method has been most productive.

The power of the method lies in the fact that the two radioactive isotopes of uranium, ${ }^{238} \mathrm{U}$ and ${ }^{235} \mathrm{U}$ decay at different rates to ${ }^{206} \mathrm{~Pb}$ and ${ }^{207} \mathrm{~Pb}$ respectively. Thus any uraniferous mineral has two radioactive clocks within it, and if both give the same age then this can be accepted with confidence as being completely reliable. However, it is of ten found that the ages are not the same, and this can commonly be shown to be due to loss of the daughter product, lead. Such discordant ages may seem at first glance to be of little value, but elegant mathematical models with simple graphical expression now enable the extraction of a remarkable amount of information from a seemingly confused pattern of discordant ages.

The approach is to separate several zircon concentrates from the same rock. These generally differ slightly in their density, grain size or magnetic properties. When the results of the analysis for the parent and daughter isotopes are plotted on the diagram shown in Figure 2 it is commonly found that the analytical data define a straight line called a 'discordia' which cuts the mathematically constructed curve, 'concordia', in two places, the upper intersection corresponding to the original age of the zircons, and the lower intersection to the age of a later metamorphism responsible for lead loss.

Figure 2 illustrates this technique applied to the evolution of the Witwatersrand conglomerates. In these rocks, uraniferous minerals, mainly uraninite, were derived from quartz veins formed initially at $3050 \pm 50 \mathrm{Ma}$ (as indicated by the two samples giving virtually concordant $\mathrm{U}: \mathrm{Pb}$ ages on the concordia line at point A). Uplift, erosion and deposition of the uraninites in the Witwatersrand conglomerates at about $2600 \mathrm{Ma}$ appears to have had no effect on the age patterns. However, metamorphism due to the emplacement of the Bushveld Igneous Complex to the north of the Witwatersrand basin caused loss of lead from many of the uraninites and reset their ages at about $2000 \mathrm{Ma}$ (point $\mathrm{B}$ on the concordia). Two of the analyzed samples which experienced only partial loss of lead plot appropriately on the discordia line A-B between about $3000 \mathrm{Ma}$ and $2000 \mathrm{Ma}$. 
Further loss of lead has occurred in recent time, possibly as the result of Karroo volcanic activity, and samples which would originally have plotted on the concordia at point $B$ $(2000 \mathrm{Ma})$ have been displaced along the line B-O. Samples plotting along the line A-O have had a simpler history. They formed at $3050 \pm 50 \mathrm{Ma}$ and were subsequently deposited in the southern part of the basin far enough away from the Bushveld Complex to have escaped thermal rejuvenation. They have however experienced more recent lead loss, perhaps also due to Karroo volcanism, and have been displaced along the discordia A-O.

In addition to analyzing different concentrates of zircons from the same rock some recent investigators have analyzed individual zircon crystals and even fragments of crystals. Such studies are capable of revealing to a remarkable extent the history of the analyzed zircons. For example, in an outstanding study of zircons from the In Ouzzal charnockites of the Hoggar, Lancelot, Vitrac and Allègre (1976) were able to reconstruct a history involving original igneous intrusion at about $3200 \mathrm{Ma}$ followed by weathering, sedimentation and later a high grade metamorphism of the sediments at about $2100 \mathrm{Ma}$.

Unfortunately the number of laboratories which routinely undertake $\mathrm{U}: \mathrm{Pb}$ dating of zircons and other accessory minerals is small, and very few laboratories have been able to make analyses on individual zircon grains. The power of the method is so impressive however that such studies are probably the ultimate goal of most established laboratories.

\section{Potassium:Argon}

The potassium:argon method is much used in reconnaissance studies, and especially in the dating of basalts and dolerites which are not particularly amenable to $\mathrm{Rb}: \mathrm{Sr}$ or $\mathrm{U}: \mathrm{Pb}$ studies. The K:Ar method is also the only method that can be readily used to date very young rocks - less than about $10 \mathrm{Ma}$. Because different minerals have different argon retention properties it is preferable to separate and analyze only the minerals known to retain Ar well: muscovite, biotite, hornblende and the high temperature volcanic feldspars.

A popular variant of the method in recent years has been to convert some of the ${ }^{39} \mathrm{~K}$ into ${ }^{39} \mathrm{Ar}$ by irradiation in a fast neutron flux. The age can then be calculated from a measurement of the ${ }^{40} \mathrm{Ar}:{ }^{39} \mathrm{Ar}$ ratio, the ${ }^{39} \mathrm{Ar}$ in effect substituting for ${ }^{40} \mathrm{~K}$. This procedure eliminates the necessity for potassium analysis, cuts out errors of sub-sampling caused by having to determine potassium and argon on separate portions, and greatly simplifies the mass spectrometric measurements. By heating the irradiated samples in a series of steps, each step at a higher temperature than the preceding one attempts have been made to elucidate polymetamorphic histories. Such investigations have had some success (e.g. Dallmeyer, 1979), but many have yielded ambiguous and uninterpretable results.

A particular aspect of $\mathrm{K}: \mathrm{Ar}$ geochronology that has attracted much attention has been the dating of sediments and the analysis of glauconites (the glauconies of Odin, 1982, p. $387-$ 406; see EPISODES, $1982 / 3$, p. 3). Again, many results have been somewhat ambiguous, but Odin has now shown that provided due attention is paid to the mineralogy and genesis of the glaucony, and particularly to its sedimentological background, very reliable ages can be obtained.

From the foregoing discussions of both the $\mathrm{U}: \mathrm{Pb}$ and $\mathrm{K}: \mathrm{Ar}$ methods it is apparent that the best results are generally those obtained from separate minerals, and it is appropriate to stress at this stage the importance of good mineralogical control of both the mineral paragenesis and the procedures used in separating and purifying the mineral concentrates. The former is often overlooked and the latter seems to present many geological laboratories with major problems. Mineral separation work is arduous and lacking in glamour compared with the sophistication of mass spectrometry, but an effective and well-organized sample preparation laboratory is an essential preliminary to all aspects of geochronological work.

\section{Rubidium:Strontium}

In the realm of crustal geology, particularly the applied aspects of geological survey and mineral exploration, the most exciting developments in recent years have involved the $\mathrm{Rb}: \mathrm{Sr}$ method. As indicated earlier the two variables here, the age of the rock and the isotopic composition of the common strontium, require the analysis of two samples if either is to be determined independently of the other. The results of such analyses are usually shown on an isochron diagram which displays variations in the amounts of the parent isotope ${ }^{87} \mathrm{Rb}$, the radiogenic daughter isotope ${ }^{87} \mathrm{Sr}$ and the common strontium conventionally expressed in terms of ${ }^{86} \mathrm{Sr}$. These three components are displayed in a two dimensional diagram by plotting the isotope ratios ${ }^{87} \mathrm{Rb}:{ }^{8} \mathrm{Sr}$ on the $x$ axis, and ${ }^{89} \mathrm{Sr}:{ }^{86} \mathrm{Sr}$ on the $y$ axis (Fig. 3). The ${ }^{87} \mathrm{Sr}:{ }^{86} \mathrm{Sr}$ ratio can only be determined from the mass spectrometric analysis of the strontium in the sample. The ${ }^{87} \mathrm{Rb}:{ }^{86} \mathrm{Sr}$ ratio may be determined using the isotope dilution technique, or from the $\mathrm{Rb}: \mathrm{Sr}$ weight ratio and a knowledge of the ${ }^{87} \mathrm{Sr}:{ }^{86} \mathrm{Sr}$ isotope ratio. If the weight ratio approach is used it should be stressed that it is only necessary to know the ratio, not the absolute amounts of $\mathrm{Rb}$ and $\mathrm{Sr}$.

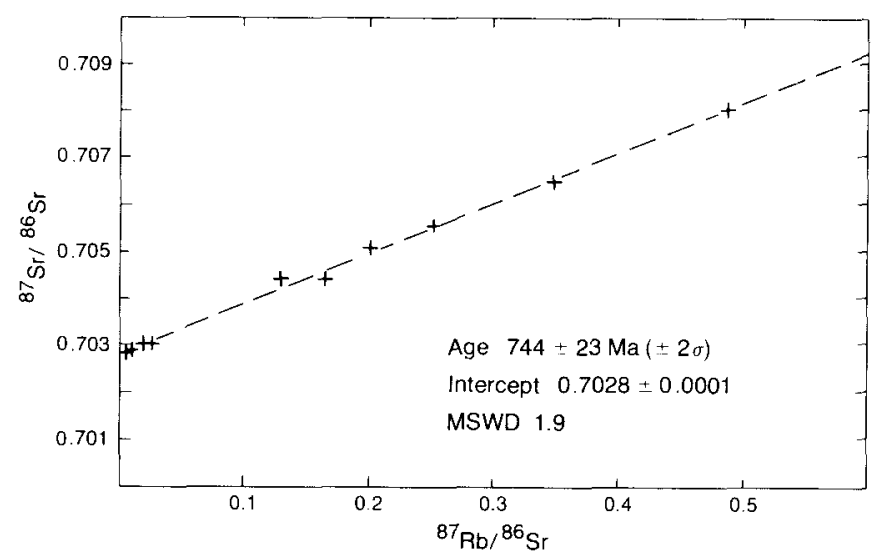

Figure 3: $R b: S r$ isochron for the Thurrat batholith, Saudi Arabia (after Marzouki et al., 1982).

If two samples crystallized at the same time, incorporating different amounts of common strontium with the same isotopic composition, their age will be a function of the slope of the straight line passing through both plotted points on an isochron diagram. Furthermore the isotopic composition of the incorporated common strontium (of considerable petrogenetic significance) expressed in terms of the initial ${ }^{87} \mathrm{Sr}:{ }^{8} \mathrm{Sr}$ ratio, will be given by the intersection of this straight line with the $y$ axis. Samples which would satisfy the requirement of being of the same age and having incorporated common strontium of the same isotopic composition would be two minerals from the same rock, say biotite and plagioclase from a granite.

Although minerals from the same rock are in theory ideal for this sort of analysis, in practice slight movements of $\mathrm{Rb}$ and $\mathrm{Sr}$ are common. Radiogenic strontium in particular readily escapes from minerals such as biotite and is equally readily absorbed by others such as the calcic minerals, plagioclase and apatite. Attention therefore switched to the analysis of the rock itself, it being argued that although the individual minerals may have been open systems, the rock as a whole 
remained a closed system. This whole rock approach has proved to be remarkably successful and is now the mainstay of $\mathrm{Rb}$ :Sr geochronology.

The fundamental requirement that the $\mathrm{Rb}$ and $\mathrm{Sr}$ contents have not changed other than by radioactive decay poses the problem of how to detect an aberrant sample, i.e. one that may have lost some radiogenic or non-radiogenic $\mathrm{Rb}$ or $\mathrm{Sr}$ as the result of some later disturbance. A resolution of this problem requires the analysis of at least four and preferably more samples. The age will then be given by the slope of a line which best fits all the analyzed samples after exclusion of those which are obviously aberrant.

Figure 3 shows an isochron for different components of the Thurrat batholith which intrudes the Precambrian basement of Saudi Arabia (Marzouki et al., 1982). In general, samples with relatively high ${ }^{87} \mathrm{Rb}:{ }^{86} \mathrm{Sr}$ ratios are more acid than those with low ratios; note that ${ }^{87} \mathrm{Rb}:{ }^{8} \mathrm{Sr}$ is about three times the $\mathrm{Rb}: \mathrm{Sr}$ weight ratio. The data points show an excellent linear array and the slope of the straight line fitted to the points indicates an age of $744 \pm 23 \mathrm{Ma}$. The intercept or initial ${ }^{87} \mathrm{Sr}:{ }^{86} \mathrm{Sr}$ ratio suggests that these granitoid rocks evolved in the mantle rather than in the continental crust (see Table 1).

The 'fit' of the straight line to the data points is indicated by the parameter MSWD (mean squared weighted deviates). Values of MSWD less than about two indicate that the scatter of the points about the line can be attributed to experimental error. Higher values would indicate 'geological error' and the reliability of the calculated age might be questionable.

The production of an isochron however requires a great deal of time-consuming work, for there are risks inherent in analyzing too few samples. The two isochrons in Figures 4 and 5 illustrate the advantage of high density analyses. The Arfan Volcanics constitute one of the basement assemblages of Saudi Arabia. Three analyses published by Fleck and others (1980) suggest an age of $761 \pm 28 \mathrm{Ma}$ (Fig. 4). However the analyses are grouped in such a way that the line is fitted to virtually two points, and aberrant points cannot be distinguished. Subsequent analyses by Darbyshire and others (in press) of twelve samples display a clear linear array with no aberrant points (Fig. 5). The fit of the straight line to these points is very good (note the MSWD parameter) and indicates an age of $598 \pm 21 \mathrm{Ma}$, which is considered to be far more reliable. The intercept suggests that these volcanics evolved in the mantle or the oceanic crust (see Table 1).

A minimum of four to five samples should therefore be investigated. The analysis of five samples by isotope dilution and in duplicate would normally represent about four manweeks' work. However, in order to find five suitable samples having a reasonable spread along the isochron, a larger number of samples would have to be collected, crushed and subjected to a preliminary Rb:Sr determination. All in all the production of a five point isochron might represent about two man-months work. At this rate a geochronological survey of an unknown terrain is not very practical, and at the best only spot checks can be made.

The first breakthrough in speeding up $\mathrm{Rb}: \mathrm{Sr}$ age determinations came when it was shown that the $\mathrm{Rb}: \mathrm{Sr}$ ratio could be determined with adequate precision and accuracy by X-ray fluorescence analysis. The second advance came with introduction of automated analysis for both $\mathrm{Rb}: \mathrm{Sr}$ by X-ray fluorescence and ${ }^{87} \mathrm{Sr}:{ }^{86} \mathrm{Sr}$ by mass spectrometric analysis. In the writer's laboratories it is now possible to make sixty $\mathrm{Rb}: \mathrm{Sr}$ ratio determinations in an automated XRF analyzer overnight (usually 30 samples in duplicate) and eight ${ }^{87} \mathrm{Sr}:{ }^{86} \mathrm{Sr}$ ratio determinations in an automated mass spectrometer every 24 hours. The machines themselves operate unattended so that the skilled scientist who previously had to sit with the machine and monitor its performance all day is now free to take up other essential jobs, such as rock crushing, chemical processing and interpretation. Needless

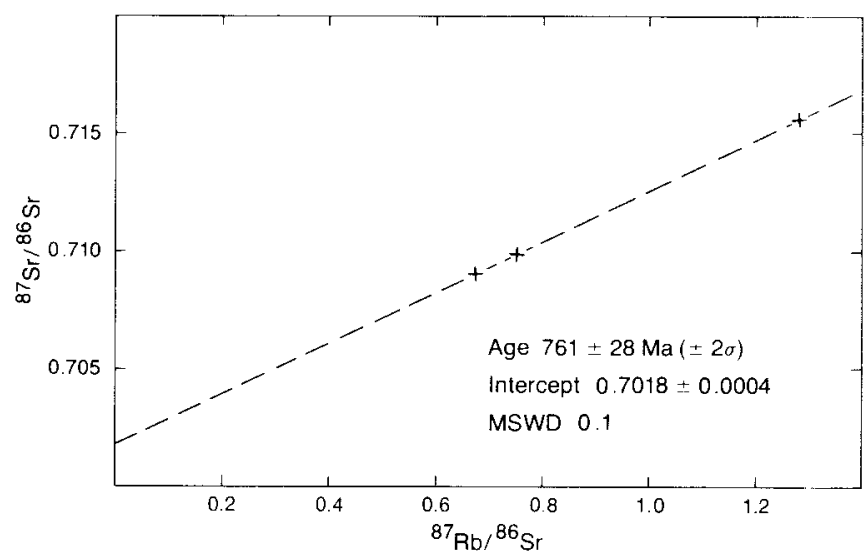

Figure 4: Three point Rb:Sr isochron for the Arfan Volcanics, Saudi Arabia (after Fleck et al., 1980).

to say, this type of automated equipment is computer controlled, and on-line computers also undertake all the data processing.

The advent of automation, coupled with great improvements in the stability and reliability of the instruments themselves clearly has the potential to revolutionize $\mathrm{Rb}: S r$ geochronology. Whereas previously little more than spot checks were possible, now high density surveys of radiometric dates on a regional scale can be contemplated. It is not claimed that this scale of $\mathrm{Rb}: \mathrm{Sr}$ investigation will answer all the questions, for there will remain the need for both $\mathrm{U}: \mathrm{Pb}$ and $\mathrm{K}: \mathrm{Ar}$ studies. Many questions will however be answered, and if coupled with modern methods of mapping - using various remote sensing techniques, satellite imagery, and aerial photography - such regional geochronological surveys will transform both the rate of geological mapping of continental terrains and our understanding of the geological evolution of such terrains.

\section{Samarium:Neodymium}

The Sm:Nd method is analogous to the R:b:Sr in that ages are calculated from isochrons which yield both an age and an initial ratio, in this case ${ }^{143} \mathrm{Nd}:{ }^{144} \mathrm{Nd}$. The geochemistry of $\mathrm{Sm}$ and $\mathrm{Nd}$ is such that the parent isotope tends to be relatively enriched, and the daughter isotope relatively im poverished in basic and ultrabasic rocks, the opposite to $\mathrm{Rb}$ and $\mathrm{Sr}$. Thus the $\mathrm{Sm}$ :Nd method can be applied to basic and ultrabasic rocks which are normally beyond the range of $\mathrm{Rb}: \mathrm{Sr}$ techniques. Furthermore, $\mathrm{Sm}$ and Nd are geochemically relatively immobile elements, and Sm:Nd ages are less

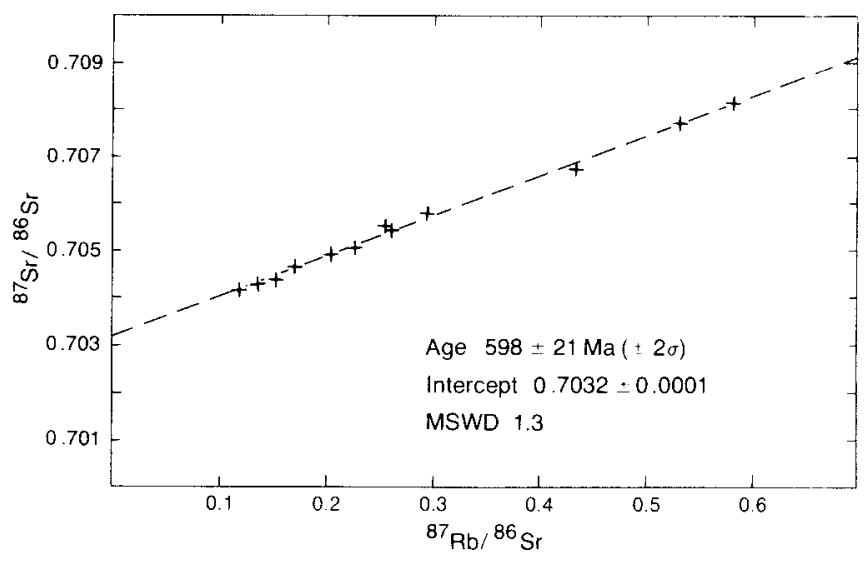

Figure 5: Revised and extended Rb:Sr isochron for the Arfan Volcanics, Saudi Arabia (after Darbyshire et al., in press). 
affected by subsequent low grade metamorphic events than are $\mathrm{Rb}: \mathrm{Sr}$ ages, which are relatively easily disturbed. However, because of the long half-life of ${ }^{147} \mathrm{Sm}$ the accumulation of the daughter product is slow, and so far the Sm:Nd dating method has mainly been applied to Archaean and Early Proterozoic rocks.

\section{Initial Isotope Ratios: A Key to Petrogenesis}

As discussed earlier, initial ratios are indicators of the isotopic composition of the daughter elements at the time of formation of the rock in question. This in turn reflects the parent to daughter ratio of the source region, and initial ratios are thus of considerable genetic significance. For example an igneous rock with a low initial ${ }^{89} \mathrm{Sr}:{ }^{86} \mathrm{Sr}$ ratio of 0.703 is likely to have originated in a source region with a low $\mathrm{Rb}: \mathrm{Sr}$ ratio, either the mantle or the lower crust. A high initial ${ }^{87} \mathrm{Sr}:{ }^{86} \mathrm{Sr}$ ratio of 0.711 would indicate an origin in an environment characterized by a high $\mathrm{Rb}: \mathrm{Sr}$ ratio such as the upper crust. Similar inferences can be made concerning the $\mathrm{Sm}: \mathrm{Nd}$ and $\mathrm{U}: \mathrm{Pb}$ ratios in the source region of igneous rocks from their initial ${ }^{143} \mathrm{Nd}:{ }^{14} \mathrm{Nd}$ and ${ }^{206} \mathrm{~Pb}:{ }^{204} \mathrm{~Pb}$ ratios respectively. The geochemical characteristics of the various levels of the crust and of the upper mantle and the resultant initial ratios are summarized in Table 1. The terms 'high', 'low', 'radiogenic' and 'nonradiogenic' are of course only relative to one another. Nevertheless, the investigation of the initial ratios of these three decay systems is becoming increasingly significant in petrogenetic and metallogenetic studies.

\section{Practical Difficulties and Some Suggested Guidelines}

Having painted this rosy picture of the future however, it is necessary to face a number of serious problems. The cost of an automated mass spectrometer suitable for Rb:Sr geochronology (Fig. 1) is of the order of $\$ 250000$ (U.S.) not including the cost of about five man-years devoted to training. Not many countries can afford this sort of outlay, either of capital or of skilled manpower, and funds and efforts could probably be better devoted to the development of geochemical prospecting programs. Still, consider the benefits to a geochemical prospecting program of well-defined objective areas, the essential geology of which was basically understood.

The costs and skilled manpower requirements thus involved are such that modern geochronological projects should be tackled on a cooperative basis. Many existing laboratories are willing to undertake joint programs, but since most of them are short of both funds and people there are severe limitations to the extent of such collaboration. Furthermore, few laboratories at the moment are automated, and with little chance of the necessary dramatic increases in funding that automation would require, progress is likely to remain disappointingly slow.

A particular problem in cooperative projects is that of continuity. Universities rightly value their academic freedom and, although a joint project may be very appealing at one particular time, changes in research direction or staff may make a cooperative geochronological survey in one of the more remote parts of the world much less attractive a year or so later. At government levels, those involved in technical cooperation know well how changes in political climate can drastically affect collaborative work, even when excellent personal relations exist between the scientists concerned.

Naturally, some countries want to establish their own geochronological laboratories, but the difficulties should not be underestimated. If the essential equipment is donated by one of the international organizations, the ready availability of hard currency for spares must be assured. Even if such funds are available, however, one must recognize that the efforts and enthusiasm of scientists are all too often thwarted by the lack of a reliable administrative service capable of processing orders and expediting delivery of new or repaired equipment. The writer knows of one case where an item that had to be returned to the manufacturer for repair or modification was held up for two years by the paper work involved.

This lack of administrative back-up can be a major problem. There are at least five adequately equipped laboratories, in countries with no serious hard currency problems, which have proved to be virtually inoperable for more than three years because of the inadequacy of national administrative services. And, of course, a geochronological laboratory is no asset if all one's field vehicles are broken down and the library and records systems have been allowed to degenerate.

\begin{tabular}{|c|c|c|c|c|c|}
\hline Mantle & \multirow{2}{*}{\multicolumn{2}{|c|}{$\begin{array}{ll}\text { Low } & \begin{array}{l}\mathrm{Rb} / \mathrm{Sr} \\
87 \\
\end{array}{ }^{\mathrm{Sr} /} /^{86} \mathrm{Sr}\end{array}$}} & High & $\begin{array}{l}\mathrm{Sm} / \mathrm{Nd} \\
{ }^{143} \mathrm{Nd} /{ }^{144} \mathrm{Nd}\end{array}$ & $\begin{array}{l}\text { High U/Pb } \\
\text { Radiogenic Pb }\end{array}$ \\
\hline $\begin{array}{l}\text { Lower crust, } \\
\text { granulite facies }\end{array}$ & & & \multirow{3}{*}{ Low } & \multirow{3}{*}{$\begin{array}{l}\mathrm{Sm}_{\mathrm{m}} / \mathrm{Nd} \\
143 \mathrm{Nd} /{ }^{144} \mathrm{Nd}\end{array}$} & \multirow{2}{*}{$\begin{array}{l}\text { Low } \mathrm{U} / \mathrm{Pb} \\
\text { Nonradiogenic } \mathrm{Pb}\end{array}$} \\
\hline $\begin{array}{l}\text { Intermediate level } \\
\text { crust, amphibolite } \\
\text { facies }\end{array}$ & \multirow{2}{*}{\multicolumn{2}{|c|}{$\begin{array}{ll}\text { High } & \mathrm{Rb} / \mathrm{Sr} \\
& 87_{5 r} /^{86} \mathrm{Sr}\end{array}$}} & & & \\
\hline High level crust & & & & & $\begin{array}{l}\text { High U/Pb } \\
\text { Radiogenic Pb }\end{array}$ \\
\hline
\end{tabular}

Table 1: Geochemical characteristics of the crust and mantle and the resulting isotopic signatures imposed on igneous rocks originating at different levels.

Even if these hurdles are overcome, there is the problem of arranging the right training for the right people and ensuring that they will not promptly leave geochronology for more administrative positions. The difficulties of training must also be borne in mind, for increasingly the advent of computers and automation means that the operator only need put the program tape into the computer and press the start button. Those of us in such laboratories must ask ourselves how we can back-track through the years of personal involvement and development for the benefit of the trainee.

Geochronology today is poised for a breakthrough, the ef fects of which in some fortunate regions will be dramatic. Elsewhere it is still not too late to 'do your own thing', though the very real difficulties involved must be squarely and honestly faced. Potential geochronologists should probably start with $\mathrm{K}: \mathrm{Ar}$ dating. It will produce useful results, and the cost of the equipment is not astronomical - about $\$ 35000$. It is best if one assembles the equipment oneself, for this in itself is valuable training. The data processing is not so unduly tedious and can be done with a chart recorder, a ruler, a simple hand calculator or even a set of old fashioned log tables.

\section{The Role of the Subcornmission on Geochronology}

The Subcommission on Geochronology of the IUGS International Commission on Stratigraphy can be of assistance here. Its essential role is the assessment and coordination of geochronometric data relating to the definition of the Geologic Time Scale. As a necessary preliminary to this task, however, the Subcommission has been much concerned in the past with the determination and standardization of decay constants of the various decay systems. This problem was essentially resolved at the 25th International Geological Congress in Sydney, Australia in 1976 when the Subcommission, under the Chairmanship of Prof. Emilie Jäger of Bern, Switzerland, proposed conventional decay constants which have now been adopted by the geochronological community world-wide (Steiger and Jäger, 1977). 
As reported in EPISODES (1982/2, p. 26-28), the Subcommission recently co-sponsored a symposium entitled "Geochronology and the Geological Record" the proceedings of which will include multi-author re-evaluations of the Phanerozoic Time Scale. Other notable publications by members of the Subcommission include "Numerical Dating in Stratigraphy" (Odin, 1982 - see EPISODES 1982/3, p. 3-9), the report on IGCP Project $99 / 118$ published as a special issue of Precambrian Research (v. 18, no.1/2, 1982) and a guide to fission track dating (Hurford and Green, 1982).

The Subcommission, through its Chairman, will be happy to provide information on geochronological matters or to refer requests to others. Those contemplating the establishment of geochronological facilities are urged to seek advice. By its very nature geology is an international science and its practitioners are naturally inclined to be cooperative.

\section{References:}

Dallmeyer, R.D., 1979. ${ }^{40} \mathrm{Ar} /{ }^{39} \mathrm{Ar}$ dating: principles, techniques and applications in orogenic terranes. In: Jäger, E., and Hunziker, J.C. (eds.), Lectures in Isotope Geology, Springer-Verlag, Berlin, Heidelberg, New York, p. 77-104.

Darbyshire, D.P.F., Jackson, N.J., Ramsay, C.R. and Roobol, M.J., in press. Rb-Sr isotope study of latest Proterozoic volcano-sedimentary belt in the central Arabian Shield. Journal of Geological Society. London.

Fleck, R.J., Greenwood, W.R., Hadley, D.G., Anderson, R.E. and Schmidt, D.L., 1980. Rubidium-strontium geochronology and plate tectonic evolution of the southern part of the Arabian Shield. Report U.S. Geological Survey. Saudi Arabian Project 245, 105p.

Holmes, A., 1932. The Origin of Igneous Rocks. Geological Magazine, v. 69, p. 543-558.

Hurford, A.J. and Green, P.F., 1982. A user's guide to fission track dating calibration. Earth and Planetary Science Letters, v. 59, p. 343-354.

Lancelot, J.R., Vitrac, A. and Allégre, C.J., 1976. Uranium and lead isotopic dating with grain-by-grain zircon analy-

\section{NEW IUGS PUBLICATION}

\section{THE ORDOVICIAN SYSTEM IN SOUTHWESTERN EUROPE (France, Spain and Portugal): Correlation Chart and Explanatory Notes}

\section{by}

W. Hammann, M. Robardet and M. Romano with the collaboration of M.D.Gil, J.C. Gutierrez, P. Herranz, A. Marcos, J. Martin, J.R. Palaez, A. Perez-Estaun, M. Prieto, I. Rabano, M.A. de San Jose, J. Trujols, R. Vegas, L. Vilas, E. Villas and J. Villena.

IUGS Publication 11, 1982, 47p., 1 map and 1 correlation chart. Sponsored by IUGS Subcommission on Ordovician Stratigraphy. \$7.50 (U.S.)

Available from:
EPISODES

or

601 Booth Street,

Room 177

Ottawa, Ontario

Canada K1A OE8 sis: a study of complex geological history with a single rock. Earth and Planetary Science Letters, v. 29, p. $357-$ 366.

Marzouki, F.M.H., Jackson, N.J., Ramsay, C.R. and Darbyshire, D.P.F., 1982. Composition, age and origin of two Proterozoic diorite-tonalite complexes in the Arabian shield. Precambrian Research, v. 19, p. 31-50.

Odin, G.S. (ed.), 1982. Numerical Dating in Stratigraphy, John Wiley \& Sons, Chichester, 2 vol., 1040p.

Rundle, C.C. and Snelling, N.J., 1977. The geochronology of uraniferous minerals in the Witwatersrand Triad; an interpretation of new and existing $\mathrm{U}-\mathrm{Pb}$ age data on rocks and minerals from the Dominion Reef, Witwatersrand and Ventersdorp supergroups. Philosophical Transactions of the Royal Society of London, Series A, v. 286, p. 567-583.

Steiger, R.H. and Jäger, E., 1977. Subcommission on Geochronology: convention on the use of decay constants in geo- and cosmo-chronology. Earth and Planetary Science Letters, v. 36, p. 359-366.

\section{ABOUT THE AUTHOR}

Dr. Norman J. Snelling is Officer-in-Charge of the Isotope Geology Unit of the Institute of Geological Sciences at 64-78 Gray's Inn Road, London WC1X $8 \mathrm{NG}$, U.K. He has been deeply involved in technical cooperation and South America. He is current chairman of the IUGS Subcommission on Geochronology, and co-author with the late Lucien Cahen of 'The geochronology of Equatorial Africa' (North Holland, 1966) and 'The geochronology and evolution of Africa' (Oxford University Press, in press). in Africa, South East Asia, India,

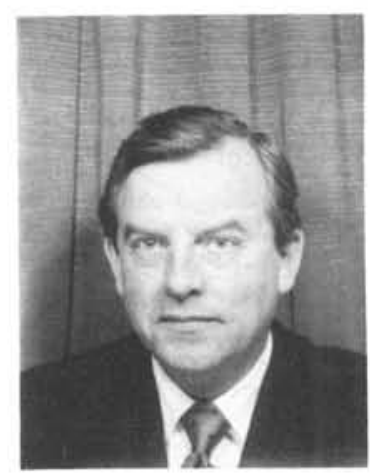

HELP BRIDGE THE COMMUNICATION GAP WITH A GIFT SUBSCRIPTION TO EPISODES

Subscribe to EPISODES at $\$ 15 /$ year and you can purchase a second "Buddy" subscription at $\$ 10$ for a colleague or institution of your choice in a developing country.

Or, simply designate the region, and we will assign your subscription to a library in need.

- I am already a subscriber

- Please enter my subscription at \$15 U.S. per year

Name:

Address:

City: Country:

PLEASE ADD A GIFT SUBSCRIPTION at $\$ 10$ U.S. per year for:

Name:

Address:

City: Country:

I ENCLOSE A CHEQUE FOR \$ U.S.

Note: cheques or money orders must be made payable to: EPISODES, Room 177, 601 Booth Street, Ottawa, Ontario, Canada, KIA OE8. 